\title{
Teachers' Perception on an ICT-Based Lesson Plan Workshop: Does It Improve Their Pedagogical Competence?
}

\author{
Yati Aisya Rani ${ }^{1 *}$, Dadi Satria ${ }^{2}$, Dinovia Fannil Kher ${ }^{1}$, and Carbiriena Solusia ${ }^{1}$ \\ ${ }^{I}$ English Department, Universitas Negeri Padang, Padang, Indonesia \\ ${ }^{2}$ Indonesian Department, Universitas Negeri Padang, Padang, Indonesia \\ *Corresponding author.Email: yati_aisya27@fbs.unp.ac.id
}

\begin{abstract}
In this digital era, it is proper for all parts of education providers to have skills in Information and Communication Technology (ICT) which are continuously honed and developed. ICT is the right choice as a tool to move the face-toface learning process to an online platform when the government takes policies to study, work, and worship at home. Unfortunately, teachers in schools are already comfortable with conventional teaching methods, with the characteristics of the teaching and evaluation process being carried out face-to-face, materials, practice questions and text-based exams and the lack of use of ICT giving a role in the classroom. A workshop is then needed in order to improve the teachers' competence in implementing ICT into their online teaching and learning process. This article discusses the perception of the teachers in regards of the workshop and its role in improving their pedagogical competence. Data were obtained from questionnaire and interview done to 15 Junior High School English teachers at the Regency of Pasaman, West Sumatra. The findings of the research indicate the fact that almost all teachers agree that the ICT-based lesson plan workshop does improve and enhance their pedagogical competence in terms of making suitable lesson plan, selecting and developing learning materials, and designing classroom activities. The workshop helps them to have better qualities that will evitably improve the implementation of their teaching later on.
\end{abstract}

Keywords: Teachers' Perceptions, ICT-Based Lesson Plan, Workshop, Pedagogical Competence

\section{INTRODUCTION}

The integration of Information and Communication Technology (IT) is not new to the national education system in Indonesia. At the end of 2018, as a form of support for welcoming the 4.0 industrial revolution, there was a policy in the national curriculum to return ICT as a subject so that students could better understand the basics of information technology as well as be proficient in using it. Prior to 2013, ICT had become one of the subjects taught at the basic education level, where students were introduced to basic understandings regarding ICT. Then in 2013 to the end of 2018, there were changes to several policies in the national curriculum which caused ICT to be eliminated as an independent subject, but integrated into all other subjects. In this period, students no longer learn about ICT, but ICT is expected to be an effective tool to maximize students and teachers in the teaching and learning process (Chaeruman, 2019). [1]

Unfortunately, during the implementation in the classroom, this integration encountered many obstacles (Fitryadi, 2013). [2] In fact, what is actually the biggest challenge is the capacity of non-ICT teachers to integrate ICT with subjects effectively in the classroom. The problems faced by non-ICT teachers are varied, ranging from the lack of teacher knowledge about ICT itself, to the untrained teachers to practice various ICT applications in the subjects they teach. Teachers consider the material in printed books to be sufficient to teach students well (Nurhayati, 2016). [3] This makes teachers think they do not need ICT in updating existing teaching materials. In addition, today's teachers are in "a comfort zone" to teach students in the traditional way. Last but not least, teachers were unmotivated in the use of ICT due to the lack of training provided to them.

Teachers' incapability of implementing ICT into their teaching, of course, is going to emerge problems regarding the recent condition of the world since the pandemic of Covid-19 hit (Sulisworo, Nasir, \& Maryani, 2017). [4] One point that should be highlighted here is related to the improvement of teachers' competence in regard of the current situation in the field of education. The Minister of Education, Culture, Research and Technology of the Republic of 
Indonesia implicitly voices an appeal for teachers to improve their competence so that they are able to run their online teaching well.

Many experts in the field of education have tried to define what is meant by "teachers' competence" (Le Van Canh, (2002), Anugerahwati, \& Saukah, (2010), Abad, (2013), Simegn, (2014), Lengkanawati, (2015), Mousavi, Atai, \& Babaii (2016), Sulistiyo, (2016), and Rinantanti, Rahman, Atmowardoyo \& Bin-Tahir, (2017)). [5], [6], [7], [8], [9], [10], [11], and [12] From their explanations, it can be concluded that teachers' competence is everything that teachers are supposed to know and have to be able to do. It is a set of knowledge, skills and behaviour of the teachers that they have to perform in order to be able to teach effectively. In Indonesia, teachers' competence is described in the Indonesian National Regulation no. 14 2005. There are 4 competences of teachers. They are pedagogic, personality, professional, and social competences. Each competence consists of several aspects that build the nature of each competence itself.

On September 2021, a workshop of developing an ICT-based lesson plan was held for English teachers of Junior High School in the Pasaman Regency of West Sumatra. The workshop was conducted with the hope of improving the teachers' pedagogical competence regarding the implementation of ICT into their lesson plan (Anyanwu, (2015), Kurnia Irmawati, Widiati \& Cahyono, (2017), Salman, \& Fattum, (2019), Shakir, Javed, \& Akhtar, (2019)). [13], [14], [15], and [16] The pedagogical competence in this study refers to the pedagogical competence proposed by Richard in Anugerahwati, \& Saukah, (2010). [6] He said that teachers' pedagogical competence is related to their competence in making suitable lesson plans, selecting and developing the suitable teaching material, as well as designing the classroom activities that engage students in learning.

However, two questions then emerge:

a. What is the teachers' perception of the workshop?

b. How does the workshop affect each aspect of their pedagogical competence?

This article tries to answer those two research questions in order to find out the English teachers' perception of the ICT-based lesson plan workshop toward their pedagogical competence.

\section{RESEARCH METHODOLOGY}

This descriptive-quantitative research was conducted in order to answer the two research questions. The samples were 15 English teachers of Junior High School in the Regency of Pasaman. Data were obtained from questionnaires and interview guides. The questionnaire was designed by using the Likert scale to figure out both the teachers' perception on the workshop and the aspects of their pedagogical competence that are influenced by participating in the workshop. Meanwhile, the interview was done in order to obtain more information of the two variables. The data then were analysed descriptively.

\section{FINDINGS}

Based on the questionnaire related to the teachers' perception on whether they think that the workshop improves their pedagogical competence, here is the following result:

Table 1. Teachers' Perception

\begin{tabular}{|c|c|c|c|c|c|}
\hline \multirow{2}{*}{ Teacher } & \multicolumn{5}{|c|}{ Perception of the ICT-based Lesson Plan Workshop } \\
\hline & $\begin{array}{c}\text { Strongly } \\
\text { Agree }\end{array}$ & Agree & Neutral & Disagree & $\begin{array}{c}\text { Strongly } \\
\text { Disagree }\end{array}$ \\
\hline 1. & $\checkmark$ & & & & \\
\hline 2. & & & $\checkmark$ & & \\
\hline 3. & $\checkmark$ & & & & \\
\hline 4. & $\checkmark$ & & & & \\
\hline 5. & $\checkmark$ & & & & \\
\hline 6. & & $\checkmark$ & & & \\
\hline 7. & $\checkmark$ & & & & \\
\hline 8. & & $\checkmark$ & & & \\
\hline 9. & & $\checkmark$ & & & \\
\hline 10. & $\checkmark$ & & & & \\
\hline 11. & $\checkmark$ & & & & \\
\hline 12. & & & $\checkmark$ & & \\
\hline 13. & & $\checkmark$ & & & \\
\hline 14. & $\checkmark$ & & & & \\
\hline 15. & $\checkmark$ & & & & \\
\hline
\end{tabular}

The data in the table can be interpreted in this following chart:

\section{Teachers' Perception}

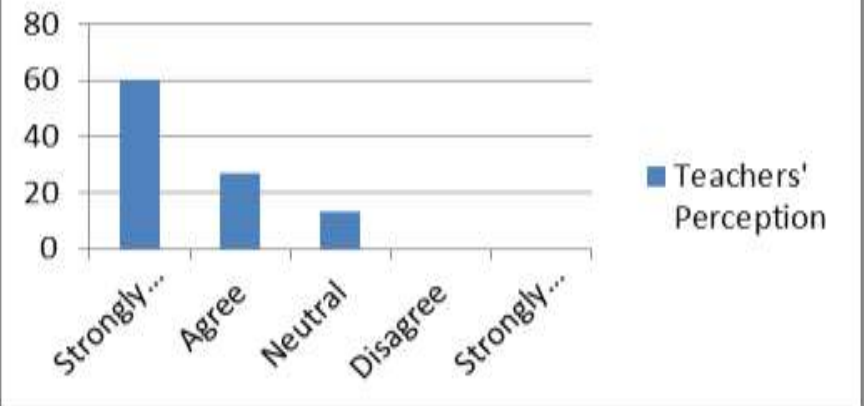

Chart 1. Teachers' Perception on the ICT-Based Lesson Plan Workshop

From the chart, it can be seen that all of them have very positive responses about the workshop. From all 15 teachers, 9 of them (60\% out of 100) strongly agree that the ICT-based lesson plan workshop does contribute 
improvements toward their pedagogical competence. 4 of them (27\% out of 100) agree that the workshop improves their competence. Other $13 \%$ are neutral about the workshop, though.

Meanwhile, for the aspects of the teachers' pedagogical competence, here is the following result:

Table 2. Aspects of Teachers' Pedagogical Competence

\begin{tabular}{|c|c|c|c|}
\hline Teacher & \multicolumn{2}{|c|}{ Aspects of Pedagogical Competence } \\
\cline { 2 - 4 } & $\begin{array}{c}\text { Making } \\
\text { suitable } \\
\text { lesson plan }\end{array}$ & $\begin{array}{c}\text { Selecting and } \\
\text { developing } \\
\text { suitable teaching } \\
\text { materials }\end{array}$ & $\begin{array}{c}\text { Designing } \\
\text { classroom } \\
\text { activities }\end{array}$ \\
\hline 1. & Yes & No & Yes \\
\hline 2. & Yes & Yes & Yes \\
\hline 3. & Yes & Yes & Yes \\
\hline 4. & Yes & No & Yes \\
\hline 5. & Yes & Yes & No \\
\hline 6. & Yes & Yes & Yes \\
\hline 7. & Yes & No & No \\
\hline 8. & Yes & Yes & Yes \\
\hline 9. & Yes & Yes & Yes \\
\hline 10. & Yes & Yes & Yes \\
\hline 11. & Yes & No & No \\
\hline 12. & Yes & Yes & Yes \\
\hline 13. & Yes & Yes & Yes \\
\hline 14. & Yes & No & Yes \\
\hline 15. & Yes & No & \\
\hline
\end{tabular}

The data in the table can be interpreted in this following chart:

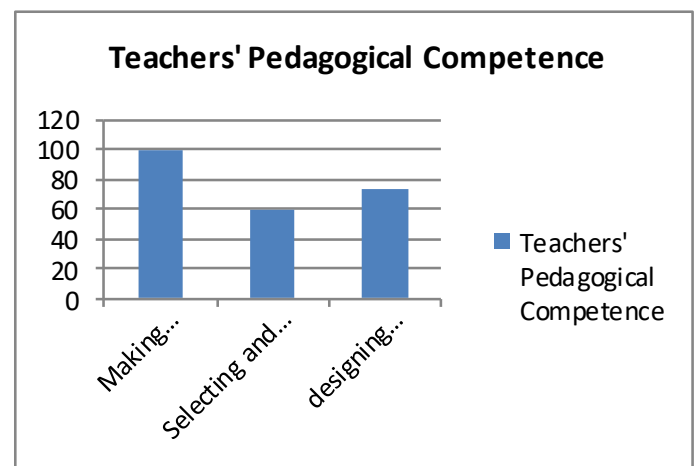

Chart 2. Aspects of Teachers' Pedagogical Competence

From the table and chart, it can be seen that the teachers' judgements on how the workshop does on the aspects of their pedagogical competence are as follows: a. $100 \%$ of the teachers do think that the ICTbased lesson plan workshop that they attended does help them to make suitable lesson plan.

b. 9 out of 15 teachers $(60 \%)$ do think that the workshop make them easier to select and develop suitable teaching materials. However, 6 of them (40\%) do not think so. They argue that the workshop does not do anything to their ability in selecting and developing their online teaching materials. They still find it difficult to do this task whenever they are about to conduct the online teaching.

c. 11 out of 15 teachers $(73 \%)$ agree that the ICTbased lesson plan workshop improve their ability in designing classroom activities. On the other hand, 4 of them (27\%) disagree to this statement and still find problems whenever they create activities for the students during their online teaching.

\section{DISCUSSION}

From the findings stated above, it can be seen that the Junior High School English teachers of the Pasaman Regency perceive the ICT-based lesson plan workshop in a very positive way. Most of them strongly agree to the fact that the workshop improves their pedagogical competence. Experts point out the advantages that teachers would gain whenever they participate in a training workshop. A workshop is "a continuous and systematic forum that aims to improve the individuals "cognition level and effective skills so that the learning achievement of the learner may be enhanced" (Shakir, Javed, \& Akhtar, (2019)). [16]

Teachers are able to gain upgrades of concepts, experience new skills, and share new ideas about the teaching and learning process. The workshop is developed when resources, speakers and peer discussions are provided. This program will certainly bring important changes that qualify academic reforms that develop professional teacher capabilities (Shakir, Javed, \& Akhtar, (2019)). [16] Other experts, Kurnia Irmawati, Widiati \& Cahyono (2017) also propose a framework on how teachers develop their pedagogical competence. [14] A workshop is one of the activities that they propose in the framework. It can be seen as follows: 


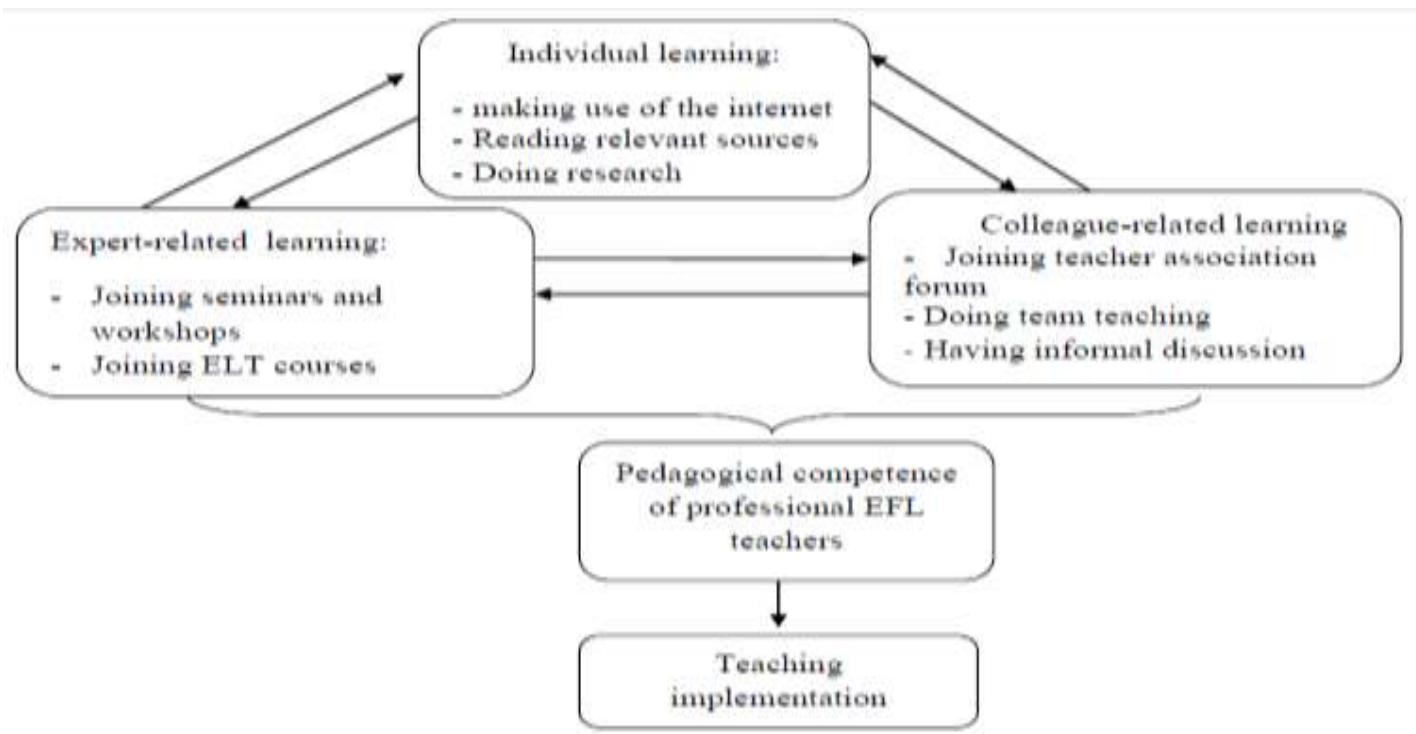

Figure 1. The framework of how teachers develop their pedagogical competence proposed by Kurnia Irmawati, Widiati \& Cahyono (2017) [14]

Regarding the aspects of the teachers' pedagogical competence, it can be analysed that all teachers agree that the ICT-based lesson plan workshop they attended help them to make suitable lesson plan for their online teaching. Of course they all think that way because the title of the workshop itself includes lesson plan in it and the lesson plan is really the main focus of the workshop being held.

However, it does not mean that the workshop only provides knowledge about lesson plan, it also implicitly include the design of learning materials and classroom activities. Why so? It is known that learning materials and classroom activities are all included in the lesson plan. They are the components of the lesson plan itself. Without the materials and activities, then teachers will not be able to implement the lesson plan into their teaching. Unfortunately, not all teachers agree to this. There are still some of them who perceive that the workshop does not really essential for the enhancement of their abilities in developing learning materials and classroom activities.

The toughest challenge is felt by those teachers since they are used to presenting materials and activities in class face-to-face and are forced to be creative in making teaching materials and activities that are able to replace teaching and learning conditions in the

classroom. It is undeniable that these teachers still feel stuttering about this condition. This could be because they do not have the expertise to utilize ICT application.

\section{CONCLUSION}

The positive perception of the English teachers on the ICT-based lesson plan workshop toward their pedagogical competence should indicate the essential role of workshop in the improvement of teachers' competence. More and more workshops need to be held in order to enhance teachers' competence since the education world changes in every aspect all the time. Teachers have to always prepare and improve their qualities in order to be able to get along with those changes

\section{AUTHORS' CONTRIBUTIONS}

All authors of this article contributed to the design and implementation of the research, to the analysis of the results and to the writing of the article's manuscript.

\section{REFERENCES}

[1] Chaeruman, U. A. Mengintegrasikan Teknologi Informasi dan Komunikasi (TIK) Ke Dalam Proses Pembelajaran: Apa, Mengapa dan Bagaimana?. Jurnal Teknodik, 2019, 046-059.

[2] Fitriyadi, H. Integrasi teknologi informasi komunikasi dalam pendidikan: potensi manfaat, masyarakat berbasis pengetahuan, pendidikan nilai, strategi implementasi dan pengembangan profesional. Jurnal Pendidikan Teknologi dan Kejuruan, 21(3), 2013.

[3] Nurhayati, T. Problematika guru dalam menguasai TIK (Teknologi Informasi dan Komunikasi) pada pembelajaran pendidikan agama Islam dan solusinya di MI Al-Asy’ari 
Kuniran Batangan Kabupaten Pati tahun ajaran 2015/2016 (Doctoral dissertation, UIN Walisongo), 2016.

[4] Sulisworo, D., Nasir, R., \& Maryani, I. Identification of teachers' problems in Indonesia on facing global community. International Journal of Research Studies in Education, 6(2), 2017, 81-90.

[5] Le Van Canh, M. A. Sustainable professional development of EFL teachers in Vietnam. Teacher's Edition, 10, 2002, 32-37.

[6] Anugerahwati, M., \& Saukah, A. Professional competence of English teachers in Indonesia: A profile of exemplary teachers. Indonesian JELT: Indonesian Journal of English Language Teaching, 6(2), 2010, 47-59.

[7] Abad, J. V. Pedagogical factors that influence EFL teaching: Some considerations for teachers' professional development. Profile Issues in Teachers Professional Development, 15(1), 2013, 97-108.

[8] Simegn, B. EFL teachers' self-initiated professional development: Perceptions and practices. Educational Research and Reviews, 9(21), 2014, 1109-1114.

[9] Lengkanawati, N. S. EFL teachers' competence in the context of English curriculum 2004: Implications for EFL teacher education. Teflin Journal, 16(1), 2015, 79-92.

[10] Mousavi, M. A., Atai, M. R., \& Babaii, E. Exploring standards and developing a measure for evaluating Iranian EFL teachers' professional competence in the private sector. Iranian Journal of English for Academic Purposes, 5(2), 2016, 30-59.

[11] Sulistiyo, U. English language teaching and EFL teacher competence in Indonesia. Proceedings of ISELT FBS Universitas Negeri Padang, 4(2), 2016, 396-406.

[12] Rinantanti, Y., Rahman, M. A., Atmowardoyo, H., \& Bin-Tahir, S. Z. Perception of Senior High School EFL Teachers in Papua, Indonesia towards Their Own Competence. Journal of Language Teaching and Research,8(6), 2017, 1181-1189.

[13] Anyanwu, K. Teachers perception in a technology integration workshop: Implications for professional development in the digital age. Issues and Trends in Educational Technology, 3(1), 2015.

[14] Kurnia Irmawati, D., Widiati, U., \& Cahyono, B. How Do Indonesian Professional English Teachers Develop Their Pedagogical Competence in Teaching Implementation?. Arab World English Journal (AWEJ) Volume, 8, 2017.

[15] Salman, E., \& Fattum, A. The Impact of Preservice and New Teachers' Involvement in Simulation Workshop and Their Perceptions about the Concept of Conflict in Education. Interdisciplinary Journal of ELearning \& Learning Objects, 15, 2019.

[16] Shakir, M. A., Javed, M., \& Akhtar, A. S. Teachers' Perception about Effects of Teacher Training Workshop on Professional Skills of Teachers Teaching at Federal Government Educational Institutions, 2019. 